\title{
IMPLIKASI KUNJUNGAN WISATAWAN GAY DI SEMINYAK, BALI
}

\author{
Ni Putu Diah Prabawati \\ Universitas Udayana \\ Email: prabadiah@gmail.com \\ A.A. Ngurah Anom Kumbara \\ Universitas Udayana \\ Email: anom_kumbara@unud.ac.id \\ Ida Bagus Gde Pujaastawa \\ Universitas Udayana \\ Email: ibg_pujaastawa@yahoo.co.id
}

\begin{abstract}
Gay tourist visits are a paradoxical phenomenon when viewed from the concept of Balinese cultural tourism. However, gay tourists exist in the Seminyak, Bali area. The purpose of this study is to examine the socio-economic, cultural, health implications of gay tourist visits and the responses of local community in Seminyak. The research method used was semi-structured interviews with 20 informants. The results of this study are that gay tourist visits have a positive effect on employment and community income. The culture of society is not affected, on the contrary the community is more proactive in preserving culture. No physical and non-physical health implications were found in the community. The level of response of the some Seminyak community to gay tourist visits has become apathy, and the annoyance shown by people who feel disturbed by gay tourists. The reseachers hope that this finding is going to be take into consideration for the development of tourism in Seminyak.
\end{abstract}

Keywords: gay tourists, tourism implications, people's responses, Seminyak 


\section{Pendahuluan}

Bali memiliki magnet yang kuat untuk menarik minat wisatawan berkunjung, tidak terlepas juga wisatawan gay. Wisatawan gay diindikasi sebagai segmen pasar minat khusus yaitu niche market (Clift dan Callister, 2002). Dapat dikatakan seperti itu dikarenakan wisatawan ini memiliki sejumlah minat dan kebutuhan khusus. Kelompok wisatawan ini juga diidentifikasi sebagai pasar yang penting dan memiliki potensi yang sangat besar (Morrison, 2013). Sejalan dengan Morrison, pasar wisatawan gay mengalami perkembangan paling pesat pada industri perjalanan (ITB Berlin, 2015). Wisatawan gay juga diidentifikasi memiliki kebutuhan untuk melakukan perjananan sebagai salah satu budaya yang wajib dilakukan dan merupakan bentuk eksistensi diri (Community Marketing dan Insight, 2012). Pertumbuhan pasar wisatawan gay juga membuat tren baru dalam dinamika pariwisata Bali. Wisatawan mencari alternatif untuk mendapatkan apa yang dicita-citakan dan melakukan hal yang berbeda dari pariwisata massal (Menuh, 2016:177). Industri pariwisata, menawarkan keramahan, pelayanan prima dan tidak memandang orientasi seksual dari penikmat jasa tersebut, tidak terkecuali wisatawan gay.

Keberadaan gay di Indonesia masih merupakan hal yang tabu dan kontroversial (Oetomo, 2013). Berbeda dengan negara-negara di Eropa yang sudah lebih dahulu mengakui keberadaan wisatawan gay seperti Spanyol, Perancis, Jerman dan Belanda. Negara Amerika, Afrika Selatan, Brazil, Argentina hingga Australia sangat gencar melakukan promosi untuk menarik perhatian wisatawan ini (UNWTO, 2012). Negaranegara di atas memberikan perhatian khusus terhadap wisatawan gay dengan diadakannya perhelatan tahunan untuk gay seperti annual gay pride di Eropa dan Mardi Gras Festival yang merupakan perhelatan besar untuk kaum LGBT yang diadakan di Sydney, Australia (Garratt, 2014). Perhelatan tersebut juga ditujukan sebagai promosi negara untuk meningkatkan kunjungan wisatawan ini ke negara tersebut.

372 JUMPA Volume 05, Nomor 02, Januari 2019 
Pulau Bali merupakan destinasi favorit dunia sangat memungkinkan dikunjungi oleh beragam karakteristik wisatawan termasuk wisatawan dengan orientasi seksual gay. Terbukti dari beberapa sumber pencarian di (Google, 2017) dengan kata kunci ‘bali gay friendly destination' ditemukan sebanyak 2.670 .000 hasil, kata kunci 'bali gay' ditemukan sebanyak 14.000.000 hasil dan kata kunci 'gay bali' ditemukan sebanyak 15.600.000 hasil. Hasil penelusuran tersebut mengindikasikan bahwa banyaknya sumber yang memuat informasi tentang keberadaan wisatawan gay di Bali. Kata kunci juga disertai dengan adanya hasil lanjutan berupa "gay bar, gay spa, gay tour hingga gay travel forum". Hal ini juga dilegitimasi oleh rekomendasi (Lonely Planet, 2017) yang merupakan panduan berwisata bagi wisatawan, terdapat rekomendasi "thing to do for entertainment khususnya gay dan lesbian di Seminyak" yang berarti adanya pilihan kegiatan wisata dan hiburan untuk wisatawan gay. Kata 'gay friendly' menjadi cara pemasaran suatu destinasi dan suatu produk jasa hospitaliti untuk menarik perhatian kalangan wisatawan ini.

Meskipun masih mengalami kontoversi, akan tetapi, aktifitas wisatawan gay eksis di Seminyak. Hal ini turut juga diikuti oleh pertumbuhan sarana penunjang seperti gay bar. Pada mulanya sekitar tahuan 2006-an terdapat Mixwell Bar yang menjadi tempat wisatawan gay berkumpul, seriring dengan pertumbuhan permintaan pasar, munculah Bali Joe Bar, Bottom Up dan Face Bar. Bar-bar ini juga menawarkan hiburan yang menarik bagi wisatawan gay dan sekaligus tempat berkumpul. Dengan mencoloknya Kawasan Seminyak khususnya Jalan Camplung Tanduk ini, sehingga diberi julukan sebagai 'Jalur Gazza'(Merdeka.com, 2016). Jalur bagi komunitas lesbi, gay, biseksual, dan transgender untuk berkumpul mengekspresikan dirinya.

Masyarakat Bali menyadari keberadaan wisatawan gay dikarenakan berita pernikahan sesama jenis di Ubud pada tahun 2015 yang mengundang kontroversi (Lestari, 2015). Akan tetapi, jauh sebelum itu, sejak 1930-an, fenomena homoseksual sudah berlangsung di Bali (Vickers, 2012). Citra Bali sebagai Surga di Timur telah 
membuat Bali menjadi salah satu 'tujuan' kaum homoseksual dari Barat. Masyarakat Bali dapat menerima keberadaan kaum gay dan bersikap toleransi terhadap siapa saja yang datang berkunjung. Tidak pernah terjadi diskriminasi jika wisatawan bersikap baik.

Kehadiran wisatawan gay menjadi sebuah fenomena paradoks jika dikaitan dengan konsep pariwisata Bali yang mengacu pada konsep pariwisata budaya. Muncul ketakutan yang mungkin juga timbul akibat adanya aktifitas wisatawan gay di Seminyak, Bali. Dikhawatirkan adanya peniruan perilaku seperti gay dan penularan virus HIV AIDS yang dapat ditularkan dari adanya kegiatan seks (Denpost, 2016). Di sisi lain aktifitas wisatawan gay tetap berlangsung semarak di Kawasan Seminyak. Eksisnya keberadaan wisatawan gay di Seminyak mengindikasikan bahwa segmen wisatawan ini memiliki peluang bisnis yang menjanjikan. Bertolak belakang dengan keadaan di atas, muncul ketakutan akibat adanya aktifitas wisatawan gay di Seminyak, Bali. Tujuan dari penelitian ini adalah untuk mengkaji implikasi sosial ekonomi, budaya, kesehatan serta respon masyarakat Seminyak terhadap kunjungan wisatawan gay.

\section{Landasan Teori dan Konsep}

Konsep Pink Tourism, Wisatawan Gay, Implikasi Pariwisata dan Respon Masyarakat Pink Tourism

Pink toursim' merupakan istilah untuk perjalanan wisatawan LGBT (Huges, 2006). Warna pink telah diadopsi oleh kaum homoseksual karena segitiga pink terbalik yang harus dipakai pria gay di markas konsentrasi Nazi Jerman. Pada tahun 2004 IGLTA menyatakan Ebensten sebagai pioneer dari perjalanan gay. Perjalanan gay berarti merayakan dan menghargai perbedaan. Adanya kode gay dipakai simbol dalam mempromosikan perjalanan gay. 'Rainbow flag' atau bendera pelangi merupakan simbol 
dari kekuatan komunikasi keramahan gay dan pesan atas penerimaan gay. Sejak tahun 2001 publik mulai akrab dengan kata 'gay friendly' atau ramah gay (Guaracino, 2007). Ramah gay berarti suatu tempat dimana pada umumnya wisatawan gay dan pasangan sesama jenis aman dari kekerasan, intimidasi, ancaman dan kekerasan fisik (tempat dimana wisatawan gay dapat menggenggam tangan pasangannya.

\section{Wisatawan Gay}

Seorang gay memiliki orientasi homoseksual karena ia adalah laki-laki, sedangkan pasangan erotis, cinta, ataupun afeksinya adalah juga laki-laki. Istilah gay juga berarti orang yang meriah, periang dan menyolok (Oetomo, 2001). Tebje mengidentifikasi wisatawan gay memiliki karakteristik tertentu. Terdapat 8 karakeristik yang khas menurut (Tebje, 2006) yaitu pertama, wisatawan gay jarang bepergian sebagai bagian dari kelompok, mereka biasanya melakukan perjalanan dengan pasangan seks yang sama. Kedua, wisatawan gay lebih sering melakukan perjalanan dan beberapa kali dalam setahun daripada wisatawan pada umumnya. Ketiga, seorang gay biasanya memiliki pendapatan lebih tinggi dari pendapatan rata-rata dan beberapa tanggung jawab keluarga. Keempat, seorang gay adalah setia terhadap satu merek dan memberikan dukungan terhadap bisnis yang 'ramah gay' dan responsif terhadap iklan yang mengakui preferensi mereka. Kelima, tujuan destinasi populer gay adalah destinasi yang ramah dengan gay dan mempunyai budaya gay. Keenam, pasangan gay lebih memilih akomodasi ramah gay. Ketujuh, banyak paket liburan gay menawarkan refleksi dari kesenangan wisatawan gay yang berusia 18-30 tahun. Kedelapan, yang paling sering mengambil liburan di pasar wisatawan gay adalah kelompok umur yang lebih dari 55 tahun dan kelompok berusia 35-54 tahun. 


\section{Implikasi Pariwisata}

Implikasi pariwisata sering disebut dengan dampak yaitu an impact is a change in a given state over time as the result of an external stimulus (Hall dan Lew, 2009:54). Adapun dampak yang akan dibahas adalah:

1) Implikasi ekonomi. Prinsip implikasi ekonomi (Sharpley dan Telfer, 2008:180) dalam pariwisata terdapat manfaat ekonomi dan biaya ekonomi. Manfaat ekonomi terdiri dari kontribusi untuk neraca pembayaran/ penghasil devisa, membangkitkan penghasilan, menambah lapangan pekerjaan, kegiatan kewirausahaan. Biaya Ekonomi terdiri dari kebocoran/ kecenderungan untuk impor, ketergantungan pada pariwisata, inflasi dan eksternatitas.

2) Implikasi budaya (Sharpley dan Telfer, 2008) menyatakan kehadiran turis dan aktivitasnya dapat memberi dampak bagi masyarakat lokal seperti efek demonstrasi, kriminal, kepercayaan menjadi suatu komoditas dan prostitusi.

3) Implikasi kesehatan. Wisatawan gay ketika berwisata erat juga kaitannya dengan seks. Dari kegiatan seksual yang dilakukan adapun implikasi yang dapat ditimbulkan dari adanya hubungan seksual sesama jenis seperti HIV/AIDS, kanker anal dan kanker anal. Cara penanggulangan penyakit menular yang disebabkan oleh berganti-ganti pasangan salah satunya adalah dengan menggunakan kondom (Jatmiko,dkk, 2010).

\section{Respon Masyarakat}

Doxey (1975, dalam Hall dan Lew, 2009:175) tingkat dan bentuk iritasi masyarakat terhadap pariwisata akan dapat berubah-ubah seiring waktu. Adapun tahapan respon masyarakat dapat disimak pada gambar 1 : 


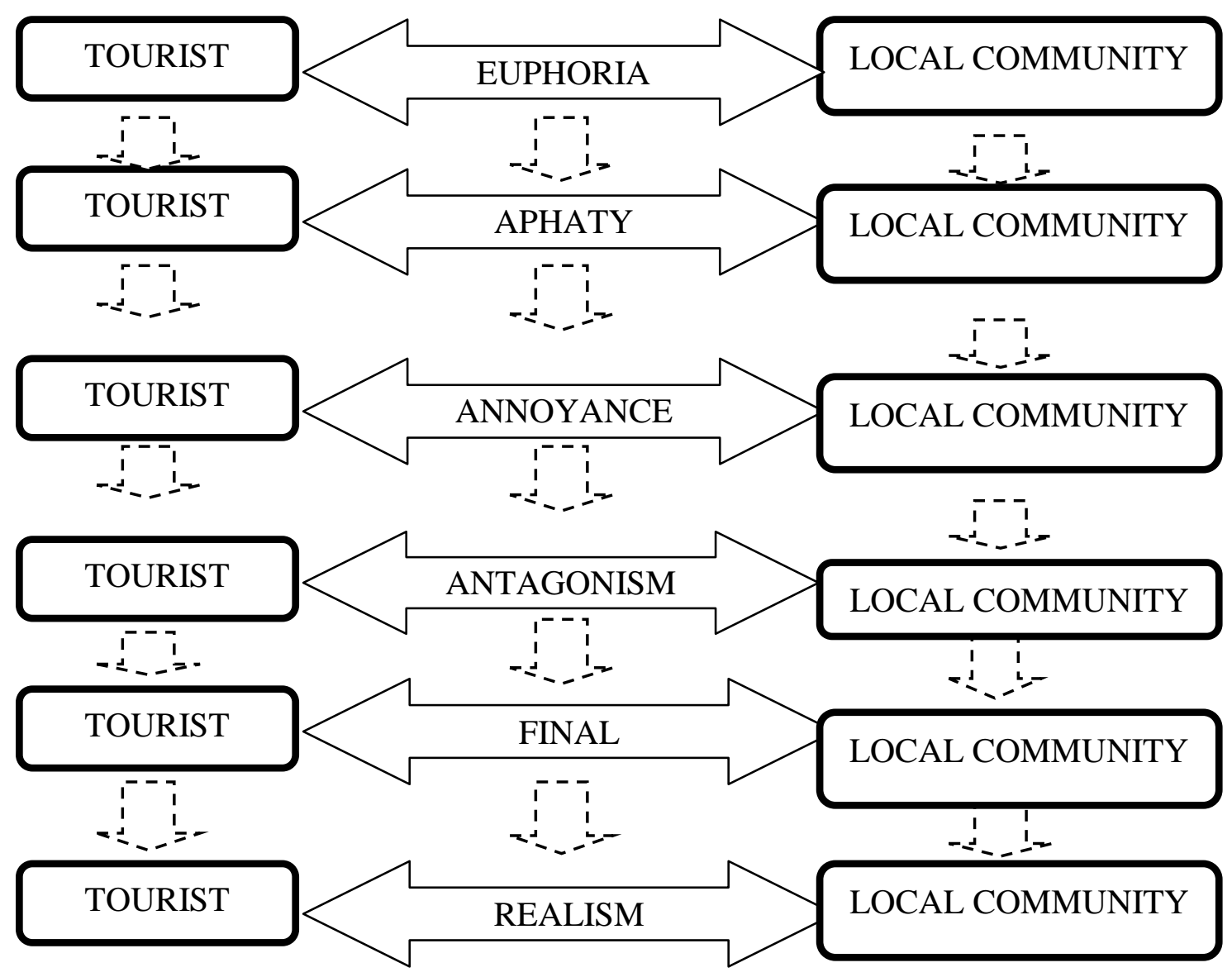

Gambar 1. Tahap-Tahap Respon Masyarakat Sumber (Hall dan Lew, 2009:175)

Gambar 2.1 menunjukkan tahapan respon masyarakat yang terdiri dari euophoria stage (perasaan bangga rohani dan jasmani), aphaty stage (sikap acuh tak acuh), annoyance stage (sikap terganggu/ terusik) dan antagonism stage (rasa benci/ pertentangan).

\section{Implikasi Kunjungan Wisatawan Gay terhadap Ekonomi Masyarakat Seminyak}

Keberadaan pariwisata di suatu daerah tentunya diharapkan membawa implikasi ekonomi bagi masyarakat setempat. Masyarakat yang tidak terlibat dalam aktivitas pariwisata pada umumnya tetap melakukan kontak dengan wisatawan karena berada di lokasi yang sama. Sesuai dengan teori interaksi, umumnya interaksi yang 
terjalin antara masyarakat dengan wisatawan hanya interaksi sementara yang bersifat transaksi ekonomi (Thelisa,dkk, 2018:233). Begitu halnya dengan kunjungan wisatawan gay di Seminyak, yang turut memberi implikasi bagi penciptaan lapangan pekerjaan dan peningkatan pendapatan masyarakat.

\section{Implikasi terhadap Penciptaan Lapangan Kerja}

Implikasi terhadap penciptaan lapangan kerja diamati secara langsung maupun tidak langsung. Secara langsung, keberadaan gay bar di Seminyak sebagai tempat tujuan wisatawan gay ke Bali telah menciptakan lapangan kerja. Adanya gay bar telah menstimulus sumber lapangan kerja, khususnya akomodasi dan transportasi di sekitar 'Jalur Gazza'. Wisatawan gay merasa senang tinggal di akomodasi yang disewakan oleh warga setempat karena lokasinya dekat dengan area gay bar dan memiliki suasananya yang nyaman. Warga pun menerima keberadaan wisatawan gay dan tidak ada sikap diskriminasi. Jika dibandingkan dengan daerah lainnya, Seminyak menawarkan akomodasi yang ramah gay. Hal tersebut menjadikan Seminyak suatu destinasi yang lengkap bagi wisatawan gay. Tidak hanya jasa akomodasi, kunjungan wisatawan gay juga memberi implikasi penciptaan lapangan kerja bagi penyedia jasa transportasi seperti taksi dan ojek. Jasa ini dibutuhkan wisatawan yang pulang dari gay bar.

Secara tidak langsung, kunjungan wisatawan gay juga berimplikasi terhadap peningkatan penjualan sarana akomodasi lain restoran, SPA, termasuk travel agent. Wisatawan gay juga kerap melakukan relaksasi sebelum menuju gay bar untuk berpesta. Mereka menghabiskan waktu untuk memanjakan diri di SPA khusus laki-laki yang banyak di jumpai di sekitar Seminyak seperti Elegantz SPA dan Banana SPA. Wisatawan gay juga mengunakan jasa agen perjalanan saat berwisata, khususnya jika mereka menginginkan yang ekslusif, seperti Bali Rainbow Tours yang khusus melayani kebutuhan wisatawan gay. 


\section{Pembahasan}

\section{Implikasi terhadap Peningkatan Pendapatan Masyarakat Seminyak}

Kunjungan wisatawan gay turut berkontribusi pada peningkatan pendapatan pemilik akomodasi di sekitar gay bar. Adanya kunjungan wisatawan gay di Seminyak juga mengisi sejumlah akomodasi milik warga dan cenderung tinggal selama 3 sampai 7 hari. Para pedagang yang membuka kios kecil menyatakan wisatawan gay yang berkunjung sering membeli dagangan mereka seperti rokok dan air mineral. Wisatawan gay pun dilayani dengan baik, sehingga tidak memandang berdasarkan orientasi seksual. Implikasi lain dikenalnya Seminyak sebagai tempat berkumpulnya wisatawan gay juga menguntungkan warga lokal. Sebab, pekerja gay atau bencong berani membayar kost-kostaan dengan harga yang lebih tinggi.

Tingkat pendapatan jasa parkir di Seminyak lebih banyak disumbang oleh wisatawan yang berkunjung ke gay bar dibandingkan tempat hiburan lainnya. Dengan kata lain, terdapat korelasi antara keberadaan gay bar dengan kunjungan wisatawan gay terhadap pendapatan atau pemasukan masyarakat. Gay bar juga turut berkontribusi pada Banjar Seminyak dengan uang pembangunan Rp. 500.000 per bulan, uang jasa keamanan Rp. 1.000 .000 per bulan, uang jasa sampah Rp. 100.000 per bulan. Gay bar membayar jasa keamanan lebih tinggi daripada usaha lainnya terutama jika mengadakan acara-acara tertentu yang mengundang keramaian dan memerlukan penjagaan khusus.

\section{Implikasi Kunjungan Wisatawan Gay terhadap Budaya Masyarakat Seminyak}

Eksistensi pariwisata Bali tidak terlepas dari budaya masyarakat lokal yang menarik wisatawan untuk datang berkunjung. Secara terotitis, implikasi budaya dilihat dari interkasi antara wisatawan gay dengan masyarakat lokal. Kunjungan wisatawan gay dapat meningkatkan atau menurunkan tatanan nilai adat-istiadat masyarakat lokal. 
Tetapi, pada prakteknya, kunjungan wisatawan gay tidak berpengaruh besar terhadap budaya masyarakat Seminyak.

\section{Implikasi terhadap Interaksi Sosial Masyarakat Seminyak}

Berdasarkan hasil penelitian, wisatawan gay tidak berinterkasi secara intensif dengan masyarakat Seminyak. Alasannya, karena aktivitas wisatawan berbeda dengan masyarakat lokal dilihat dari segi ruang dan waktu. Wisatawan gay cenderung beraktifitas pada malam hari di gay bar, sedangkan masyarakat beraktivitas pada pagi hari. Ritual keagamaan berjalan dengan lancar. Pada saat upacara keagamaan di Seminyak, wisatawan gay tidak pernah ikut terlibat seperti tamu pada umumnya.

Pada malam hari, masyarakat Seminyak rata-rata telah beristirahat di rumah masing-masing ketika wisatawan gay beraktifitas. Selain itu, pada pagi dan siang hari masyarakat lokal tidak pernah berinterkasi langsung dengan wisatawan gay, karena pada waktu tersebut mereka hanya terlihat seperti turis normal yang berwisata di Bali. Tetapi pada malam hari, perbedaan tampak jelas karena wisatawan gay berduyunduyun menuju pusat hiburan wisatawan gay di Bali Joe Bar dan Mixwell Bar.

\section{Implikasi terhadap Tatanan Adat-Istiadat Masyarakat Seminyak}

Hasil pengamatan yang dilakukan menunjukan bahwa efek demonstratif wisatawan gay tidak berpengaruh terhadap tatanan adat-istiadat masyarakat Seminyak. Sebaliknya, justru wisatawan gay merupakan pangsa pasar yang berkualitas ditinjau dari pengeluaran dan lama tinggal di Bali.

Pemuda setempat pun tidak ikut-ikutan untuk bertingkah seperti wisatawan gay. Alasanya, karena perilaku gay yang melambai tidak sesuai dengan karakteristik pemuda Bali. Pemuda Bali adalah pemuda yang digambarkan tangguh, berani, dan kreatif. Kalangan pemuda lebih memilih menjadi pihak keamanan disamping menjadi penggiat seni untuk melestarikan adat istiadatnya. Artinya, menjadi pihak keamanan bertujuan untuk menunjukan sikap tangguh dan berani dari pemuda setempat, 
sedangkan menjadi penggiat seni bertujuan untuk menunjukan bakat kreatifvitas alamiah mereka.

Apabila dianalisis secara progresif, kunjungan wisatawan gay justru memberikan nilai tambah bagi masyarakat Seminyak. Mobilitas kedatangan wisatawan gay di Seminyak berhasil menstimulus pariwisata, khususnya jasa pengelolaan tempat hiburan dan akomodasi perhotelan. Dengan stimulus yang diberikan wisatawan gay itulah, turut serta mendorong pendapatan dana desa untuk berbagai macam kegiatan.

Pada titik inilah, pendapatan dana desa memberikan berkah bagi masyarakat Seminyak. Pendapatan yang masuk ke dalam kas desa tidak hanya diperuntukan bagi program sarana dan prasarana, tetapi juga untuk upacara dan ritual keagamaan. Pihak desa pun, membuat program yang bermanfaat untuk generasi muda agar menjunjung tinggi warisan adat leluhur seperti membentuk sanggar tari untuk anak-anak, pesraman setiap hari minggu, kelompok sanggar seni sekaa gong, lomba layang-layang dan berbagai macam kegiatan positif untuk menghidari efek negatif kunjungan wisatawan gay.

Perilaku gay dari sudut pandang khalayak umum memang menyimpang, yang disebabkan perbedaan kepribadian, karakter, dan orientasi seksual. Tetapi dalam kasus Seminyak, wisatawan gay tidak mempengaruhi ruang adat istiadat karena mereka mempunyai ruang komunitas tersendiri.

\section{Implikasi terhadap Tingkah Laku Masyarakat Seminyak}

Berdasarkan hasil pengamatan dan analisis wawancara, kunjungan wisatawan gay tidak berimplikasi terhadap perubahan tingkah laku masyarakat Seminyak. Masyarakat tidak mengadopsi ekspresi wisatawan gay melalui tingkah laku, cara berpakaian, dan pengunaan bahasa. Tingkah laku yang melambai, cara berpakaian yang feminim, dan pengunaan istilah-istilah dalam komunitas gay tidak dijadikan sebagai tutur bahasa di masyarakat. 
Masyarakat Seminyak dapat dikatakan mempunyai pendirian yang teguh dengan konsep hidup orang Bali. Dalam hal berprilaku, masyarakat Seminyak akan terlihat menyimpang bila mengikuti gerak-gerik gay yang kemayu dan menyukai sesama jenis. Dalam hal ini, jika ada masyarakat yang berperilaku menyimpang, akan mendapatkan cibiran dan citra buruk di kalangan masyarakat Seminyak.

\section{Implikasi Kunjungan Wisatawan Gay terhadap Kesehatan Masyarakat Seminyak}

Secara teoritis, wisatawan gay yang mempunyai orientasi seksual berbeda akan berimplikasi terhadap kesehatan masyarakat Seminyak. Semakin banyak wisatawan gay yang mengujungi Seminyak, maka kecenderungan untuk mendapatkan teman kencan dan pasangan akan semakin besar pula. Hubungan kencan inilah yang berpotensi menimbulkan penyakit, khususnya penyakit yang berisfat fisik. Tetapi pada praketknya, implikasi kesehatan yang beroreintasi pada penyakit kelamin tidak berkorelasi dengan kesehatan fisik masyarakat. Hal ini dikarenakan masyarakat Seminyak bukanlah pelaku dalam aktivitas tersebut.

Adanya lokasi atau hot spot di Seminyak memiliki potensi resiko implikasi terhadap penularan penyakit HIV/AIDS. Perda Kabupaten Badung 1 Tahun 2008 pada pasal 10 juga mengatur beberapa kewajiban dari usaha yang memiliki resiko terhadap kesehatan seperti para pemilik dan/ atau pengelola tempat hiburan. Pengusaha wajib memberikan informasi atau penyuluhan secara berkala mengenai pencegahan HIV dan AIDS kepada semua karyawannya.

Titik kumpul atau'hot spot' diatur pada pasal 9, yang didefiniskan bahwa setiap orang yang melakukan hubungan seksual berisiko wajib melakukan upaya pencegahan dengan memakai kondom. Dengan kata lain, hot spot merupakan lokasi yang wajib dijangkau dan disosialisasikan untuk penggunaan kondom. Potensi penularan ini hendaknya dapat diantisipasi dengan tindakan pencegahan berupa pemeriksaan dan penyuluhan kesehatan. Penyuluhan yang dilakukan oleh pemerintah berupa kesehatan reproduksi bagi ibu-ibu dengan datang ke banjar. Dengan penyuluhan seperti ini, lebih 382 JUMPA Volume 05, Nomor 02, Januari 2019 
banyak menjangkau perempuan akan tetapi belum menjangkau para laki-laki. Perempuan lebih perhatian pada kesehatan reproduksi daripada laki-laki.

Yayasan Gaya Dewata hadir untuk membantu menjangkau, mendekati temanteman komunitas. Gaya Dewata memiliki petugas lapangan untuk menjangkau temanteman gay yang beraktifitas di Kawasan Seminyak. Petugas lapangan bertugas edukasi, pemahaman masalah kesehatan, perilaku sehat dan aman. Jika misalnya mereka pernah melakukan hubungan berresiko, jika berkenan, petugas lapangan akan merujuk temanteman komunitas ke tahap pemeriksaan untuk IMS atau penyakit kelamin dan juga HIV untuk di obati tuntas.

Berkaitan dengan aspek non fisik, implikasi kunjungan wisatawan gay juga tidak berpengaruh terhadap kesehatan non-fisik masyarakat Seminyak. Alasannya, karena masyarakat Seminyak tidak punya hasrat untuk menjadi gay. Meski muncul kekhawatiran yang dapat menganggu psikologis masyarakat lokal dari efek demonstratif wisatawan gay, tetapi masyarakat telah mengantisipasi dengan kegiatankegiatan positif agar jiwa masyarakat Seminyak tetap ajeg.

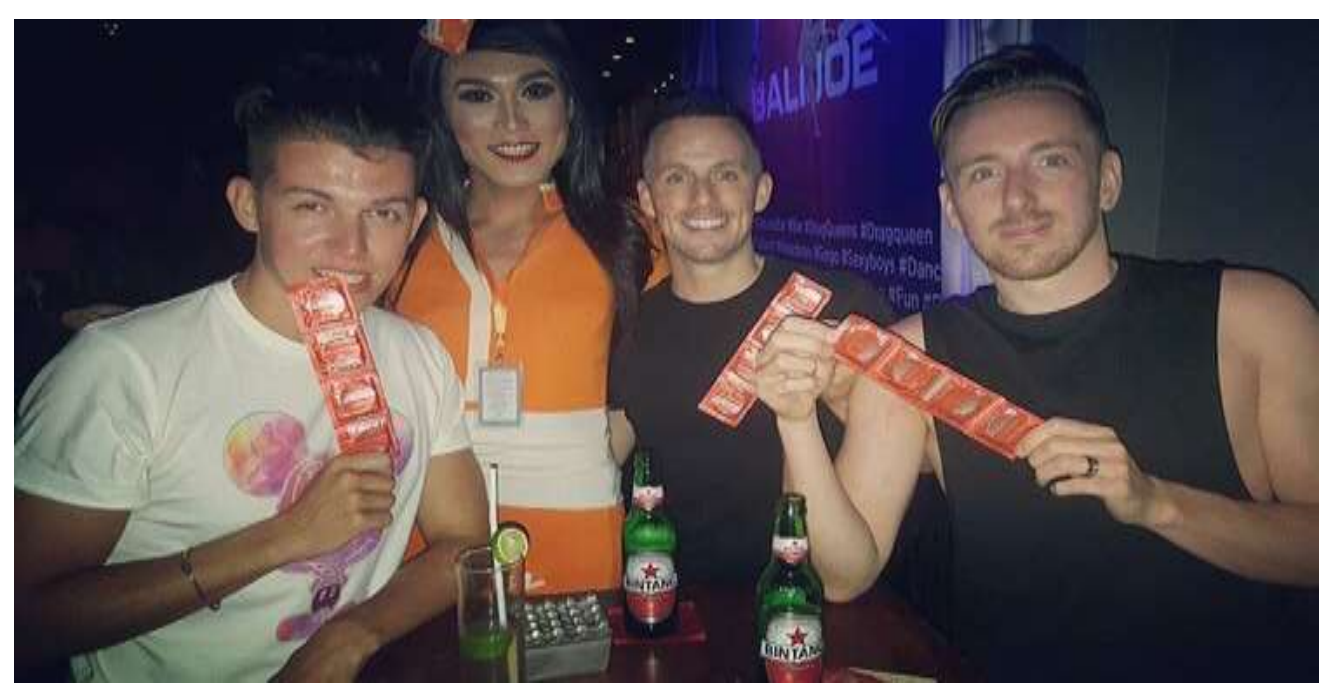

Gambar 2 Penjangkauan oleh Petugas Lapangan di Bali Joe Bar Sumber: Dokumentasi Kimora (2017) 


\section{Respon Masyarakat Seminyak terhadap Wisatawan Gay}

Tingkat respon ini ditinjau menggunakan teori Doxey (1975) irritation index (irridex). Model irridex ini menggambarkan perubahan sikap masyarakat lokal terhadap keberadaan wisatawan secara linier. Sikap masyarakat lokal terhadap kunjungan wisatawan gay didapat dari hasil pengumpulan data dengan observasi dan wawancara semistruktur dengan mewawancarai tokoh masyarakat Seminyak dan masyarakat lokal Seminyak. Adapun bentuk respon yang diteliti adalah sikap masyarakat, tanggapan masyarakat lokal terhadap citra 'Jalur Gazza' dan partisipasi masyarakat.

\section{Sikap Masyarakat Lokal terhadap Kunjungan Wisatawan Gay}

Adanya interaksi antara masyarakat lokal dan wisatawan yang berkunjung berpengaruh pada komersialisasi dari keramahtamahan masyarakat lokal. Masyarakat lokal memiliki pandangan yang terbuka terhadap fenomena wisatawan gay karena turut menstimulus pariwisata di Seminyak. Masyarakat secara umum, mengetahui wisatawan gay memiliki orientasi seksual yang berbeda dengan wisatawan heterogen pada umumnya.

Sejak tahun 2007-an, wisatawan gay mulai ramai berduyun-duyun ke Seminyak. Kegiatan wisatawan gay pada waktu itu, sangat mencolok dibandingkan dengan bar yang lain. Mereka berciuman sesama mereka dijalan saat malam hari. Bahkan, keramiannya pada akhir pekan dapat menghabiskan setengah dari bahu jalan. Bila dibandingkan dengan tahun 2007 dengan sekarang, keberadaan wisatawan gay sekarang sudah mulai berkurang.

Pada awal mulanya sejumlah masyarakat masih merasa risih tetapi kian lama menjadi hal yang biasa. Mayoritas masyarakat tidak memanggil dengan sebutan gay, tetapi menyebutnya dengan sebutan bencong. Masyarakat Seminyak menunjukkan keterbukaan pikirannya dengan menerima kehadiran wisatawan gay. Masyarakat akan tetap bersikap baik jika wisatawan dapat bersikap sopan dan tidak mengganggu kehidupan masyarakat.

384 JUMPA Volume 05, Nomor 02, Januari 2019 


\section{Tanggapan Masyarakat Lokal terhadap Citra Seminyak Sebagai ‘Jalur Gazza’}

Tanggapan masyarakat merupakan suatu proses dimana kelompok manusia yang hidup di suatu wilayah tertentu berpendapat tentang sesuatu yang menarik perhatiannya. Dengan adanya kegiatan wisatawan gay, tentu berpengaruh terhadap citra Kawasan Seminyak yang mengundang pandangan dari masyarakat lokal itu sendiri.

Camplung Tanduk juga mendapat sorotan dari berbagai media yang memberitakan bahwa 'Jalur Gazza' merupakan jalurnya para gay dan waria berkumpul. Dari observasi dan wawancara yang peneliti lakukan terdapat beberapa tanggapan dari masyarakat. Pada awalnya masyarakat merasa daerahnya tercoreng, akan tetapi di satu sisi julukan sebagai ‘Jalur Gazza' membuat Seminyak semakin viral. Namun demikian, justru dengan julukan inilah orang-orang penasaran ke tempat itu serta membuatnya booming.

\section{Partisipasi Masyarakat Lokal terhadap Kunjungan Wisatawan Gay}

Perkembangan pariwisata tidak dapat terpisahkan dari adanya dukungan dari masyarakat lokal berupa partisipasi dalam setiap kegiatan pariwisata. Masyarakat yang tidak terlibat langsung dalam kegiatan juga mendapatkan distribusi keuntungan. Partisipasi masyarkat diwujudkan dalam mengambil bagian atau peran dalam pembangunan, baik dalam bentuk pernyataan mengikuti kegiatan, memberi masukan berupa pemikiran, tenaga, waktu, keahlian, modal, dana atau materi, serta ikut memanfaatkan dan menikmati hasilnya.

Masyarakat Seminyak sangat merasakan manfaat dari kehadiran pariwisata dan jeli melihat peluang. Masyarakat diberdayakan dengan mengelola warung yang terdapat di Pantai Seminyak, mengelola sampah hasil industri pariwisata dan tergabung dalam organisasi BAPEDES (Badan Pembangunan Desa Adat Seminyak). Masyarakat lokal mau berpartisipasi dalam kegiatan pariwisata agar tidak semua 
diambil oleh orang luar. Namun, masyarakat lokal Seminyak tidak pernah ikut serta dalam mempromosikan daerahnya dengan menyediakan hiburan khusus gay.

\section{Tingkat Respon Masyarakat Lokal}

Sikap masyarakat yang pada awalnya positif semakin lama dengan pertambahan jumlah wisatawan menjadi negatif. Respon masyarakat lokal Seminyak berada pada tahapan apathy dan annoyance sebagai berikut:

Pada respon apathty terjadi pada masyarakat yang berkecimpung dan menikmati hasil dari pariwisata tersebut. Masyarakat menerima semua sesuatu dengan lumrah dan hubungan yang terjadi antara masyarakat dengan wisatawan didominasi motif komersial. Respon apathy yang terjadi dari keberadaan wisatawan gay adalah sikap tidak peduli atas keberadaan wisatawan gay dan yang terpenting bisa mendapatkan uang dari apa yang di butuhkan oleh mereka, seperti transportasi, pijat, restoran, parkir dan warung-warung kecil di sekitar area tersebut.

Hal ini terbukti keberadaan wisatawan gay di Seminyak mendapat respon baik dari masyarakat lokal yang mendapatkan keuntungan dari adanya wisatawan gay yang berkunjung. Respon dari masyarakat pendatang yang menggantungkan hidupnya dari keberadaan wisatawan ini seperti supir taksi, supir ojek, juru parkir Seminyak dan pengusaha toko yang menjual keperluan wisatawan gay.

Pada tingkat annoyance adalah masyarakat lokal merasakan titik kejenuhan sudah hampir dicapai, dan masyarakat mulai merasa terganggu dengan kehadiran wisatawan. Respon annoyance ini terjadi pada sebagian masyarakat yang memiliki usaha seperti akomodasi yang berdekatan dengam gay bar dan tidak mendapatkan keuntungan dari adanya keberadaan wisatawan gay.

Hal tersebut dikarenakan keberadaan hiburan gay hanya membuat kebisingan dan perbedaan budaya yang dibawa oleh wisatawan. Sesuai dengan hasil wawancara, informan yang terdiri dari masyarakat lokal terhadap keberadaan wisatawan gay di Seminyak. Terdapat berbagai macam bentuk respon terhadap keberadaan wisatawan 386 JUMPA Volume 05, Nomor 02, Januari 2019 
gay. Masalah tentang aktivitas gay bar adalah hal yang klasik karena ketika pertemuan di banjar hal tersebut selalu menjadi keluhan karena selalu membuat kebisingan.

Dahulu pernah terjadi penutupan total, tetapi itu juga berdampak pada sepinya Kawasan Seminyak. Yang terjadi sekarang adalah masyarakat memberikan sedikit kelonggaran terhadap aktifitas gay bar dan tetap mematuhi aturan yang telah di ditetapkan oleh Desa Adat Seminyak. Kepala Lingkungan sudah melaporkan keluhan masyarakat dan berencana untuk menutup gay bar, masyarakat akan berusaha menutup kegiatan tersebut saat memperpanjang ijin.

\section{Simpulan dan Saran}

Berdasarkan seluruh informasi di atas, dapat disimpulkan bahwa kunjungan wisatawan gay merupakan suatu fenomena yang paradoks. Disatu sisi kunjungan wisatawan gay masih bersifat kontroversial. Pada satu sisi lainnya, kunjungan wisatawan gay dimanfaatkan masyarakat setempat sebagai peluang untuk mendapatkan sejumlah manfaat ekonomi. Stigma yang berkembang dan ketakutan akan adanya aktifitas wisatawan gay di Seminyak terbantahkan. Hal ini karena kunjungan wisatawan gay tidak berpengaruh pada masyarakat setempat. Masyarakat menjadi lebih pro aktif mempertahankan budayanya. Implikasi kesehatan juga diminimalisir oleh tindakan pencegahan berupa penyuluhan kesehatan oleh komunitas Gaya Dewata. Dari penelitian ini diharapkan dapat menjadi masukan bagi pengembangan kebijakan pariwisata di Kawasan Seminyak, Bali dan upaya-upaya untuk menanggulangi implikasi pariwisata yang bersifat merugikan. 


\section{Daftar Pustaka}

Clift, S., L. dan Callister, C. , 2002. Gay Tourism: Yesterday, Today and Tomorrow. London: Continuum.

Denpost, A., 2016. KPA Sebut Camplung Tanduk Surga Gay. Sumber http://denpostnews.com/2016/07/05/kpa-sebut-camplung-tanduk-surga-gay/ Diakses 26/02/2017.

Garratt, L., 2014. Pride of Australia! Festival of colour as Gay Mardi Gras parade hits the streets of Sydney. Daily Mail. Sumber http://www.dailymail.co.uk/news/article2570866/Pride-Australia-Festival-colour-Gay-Lesbian-Mardi-Gras-parade-hitsstreets-Sydney.html Diakses 20/01/2018.

Google. 2017. "Bali Gay Friendly Destination". Sumber https://www.google.com/search?sclient=psyabdanbiw=1366danbih=659danq=b ali+gay+friendly+destinationdanoq=bali+gay+friendly+destinationdangs_l=hp.3 ...3296.9612.0.9923.17.13.0.0.0.0.320.1053.0j3j1j1.5.0....0...1c.1.64.psyab..12.4.730.0. .0j35i39k1.rSd3RfhGXMAdanpbx=1danb Diakses 23/07/2017.

Guaracino, J., 2007. Gay and Lesbian Tourism, The Essential Guide for Marketing. 1st ed. United Kingdom : Elsevier Ltd.

Hall, C. M. dan Lew, A. A., 2009. Understanding Impacts. In: Understanding Anding and Managing Tourism Impacts: An Integrated Approach . New York: Routledge, pp. 185.

Huges, H. L., 2006. Pink Tourism Holiday of Gay Men and Lesbian. London: CAB International.

ITB Berlin, 2015. Gay and Lesbian Travel a booming segment at ITB Berlin 2015. Sumber http://www.itbberlin.de/en/ITBBerlin/DestinationsSegments/GayLesbianTravel LGBTTravel/ Diakses 06/03/2017.

Insight, C. M. dan., 2012. 17th Annual LGBT Travel Survey, San Francisco: Community Marketing.Inc.

Jatmiko,dkk, A. C., 2010. Peranan Kondom pada Penderita HIV (The Role of Condoms in fection). Berkala Ilmu Kesehatan Kulit dan Kelamin, Vol. 22 (1), pp. 45-48.

Lestari, S., 2015. Pasca-perayaan Pernikahan Gay, Disparda Bali Ambil Tindakan, Denpasar: Kompas.com.

Lonely Planet. 2017. "Bali and Gay Lesbian Travellers". Sumber https://www.lonelyplanet.com/indonesia/bali/gay-and-lesbian-travellers Diakses 06/03/2017. 
Merdeka.com. 2016. Jalur Gazza di Pulau Dewata. Sumber https://www.merdeka.com/khas/jalur-gazza-di-pulau-dewata-lgbt-di-pulaudewata-2.html Diakses 09/09/2016.

Menuh. 2016. Karakteristik Wisatawan Backpacker dan Dampaknya Terhadap Pariwisata Kuta, Bali. JUMPA: Volume 2 Nomor 2 Januari 2016 h.177-188.

Morrison, A. M. 2013. Marketing and Managing Tourism Destinations. 1st ed. New York: Routledge.

Oetomo, Dede. 2001. Memberi Suara Pada Yang Bisu. Yogyakarta: Galang Printika.

Oetomo, Dede. 2013. Hidup Sebagai LGBT di Asia: Laporan Nasional Indonesia, Bali: Dialog Komunitas LGBT Nasional.

Sharpley, R. dan Telfer, D. J., 2008. Tourism and Development in the Developing World. 1st ed. New York: Routledge.

Tebje, M., 2006. South Africa's Promotion to the Gay Market. The Tourism Network, pp. 18.

Thelisa, dkk. 2018. Pengaruh Pariwisata Terhadap Kondisi Sosial Budaya Masyarakat KarimunJawa, Jawa Tengah . JUMPA: Volume 4 Nomor 2, Januari 2018 h. 228239.

UNWTO, 2012. Global Report on LGBT Tourism AM Reports: Volume Three, Madrid, Spain: World Tourism Organization.

Vickers, A. 2012. Bali: A Paradise Created. Periplus Edition (HK) Ltd ed. s.l.:Tuttle Publising.

\section{Profil Penulis}

Ni Putu Diah Prabawati, S.ST.Par adalah alumnus Magister Kajian Pariwisata dan mengikuti pertukaran pelajar Asian European Joint Curriculum antara Udayana dan Fachoscule Stralsund University of Applied Science. Sebelumnya, ia menyelesaikan program studi Diploma IV, Administrasi Perhotelan di Sekolah Tinggi Pariwisata Nusa Dua Bali. Ia aktif dalam organisasi kepemudaan Kesatuan Mahasiswa Hindu Dharma Indonesia dan memiliki ketertarikan dalam penelitian dengan tema pengelolaan hotel dan gender. 
A.A. Ngurah Anom Kumbara, MS. adalah dosen Fakultas Ilmu Budaya Universitas Udayana, sekaligus pembimbing utama dari penelitian tesis ini. Minat penelitiannya adalah sosiologi dan pariwisata.

Ida Bagus Gde Pujaastawa, menjabat sebagai sekertaris Konsorsium Kajian Pariwisata Udayana dan minat penelitiannya adalah budaya dan pariwisata. 